\title{
The influence of atmospheric circulation on the mid-Holocene climate of Europe: a data-model comparison
}

\author{
A. Mauri ${ }^{1, *}$, B. A. S. Davis ${ }^{1, * *}$, P. M. Collins ${ }^{1}$, and J. O. Kaplan ${ }^{1, * *}$ \\ ${ }^{1}$ ARVE Group, Institute of Environmental Engineering, Ecole Polytechnique Fédérale de Lausanne, Switzerland \\ *now at: Institute for Environment and Sustainability, Joint Research Centre, Ispra, Italy \\ ** now at: ARVE Group, Institute of Earth Surface Dynamics, University of Lausanne, Switzerland
}

Correspondence to: B. A. S. Davis (basil.davis@unil.ch)

Received: 9 September 2013 - Published in Clim. Past Discuss.: 7 October 2013

Revised: 10 August 2014 - Accepted: 18 September 2014 - Published: 29 October 2014

\begin{abstract}
The atmospheric circulation is a key area of uncertainty in climate model simulations of future climate change, especially in mid-latitude regions such as Europe where atmospheric dynamics have a significant role in climate variability. It has been proposed that the mid-Holocene was characterized in Europe by a stronger westerly circulation in winter comparable with a more positive AO/NAO, and a weaker westerly circulation in summer caused by anticyclonic blocking near Scandinavia. Model simulations indicate at best only a weakly positive AO/NAO, whilst changes in summer atmospheric circulation have not been widely investigated. Here we use a new pollen-based reconstruction of European mid-Holocene climate to investigate the role of atmospheric circulation in explaining the spatial pattern of seasonal temperature and precipitation anomalies. We find that the footprint of the anomalies is entirely consistent with those from modern analogue atmospheric circulation patterns associated with a strong westerly circulation in winter (positive $\mathrm{AO} / \mathrm{NAO}$ ) and a weak westerly circulation in summer associated with anti-cyclonic blocking (positive SCAND). We find little agreement between the reconstructed anomalies and those from 14 GCMs that performed mid-Holocene experiments as part of the PMIP3/CMIP5 project, which show a much greater sensitivity to top-of-the-atmosphere changes in solar insolation. Our findings are consistent with datamodel comparisons on contemporary timescales that indicate that models underestimate the role of atmospheric circulation in recent climate change, whilst also highlighting the importance of atmospheric dynamics in explaining interglacial warming.
\end{abstract}

\section{Introduction}

Global Climate Models (GCMs) are essential tools for investigating future climate change but their ability to simulate future climate remains uncertain, especially at the regional scale (Hawkins and Sutton, 2009; Deser et al., 2012). One of the main sources of uncertainty in determining regional climate change in the mid-latitude regions such as Europe is the atmospheric circulation, a feature of the climate system that models have difficulty to simulate (Gillett, 2005; van Ulden and van Oldenborgh, 2006; Woollings, 2010; Vial and Osborn, 2012; Brands et al., 2013).

One way to reduce model uncertainty is to perform GCM simulations of past climates, which can then be independently evaluated using palaeoclimate archives. The midHolocene (MH, 6000 years BP) has become a standard benchmark time period for this kind of data-model comparison, being sufficiently distant in the past to be substantially different from the present but close enough that the model boundary conditions are well known and actual climate conditions can be reconstructed in some detail. Climate forcing during the $\mathrm{MH}$ was primarily the result of an amplified seasonal insolation cycle, which led to higher than present insolation $\left(+5 \%\right.$ at $\left.45^{\circ} \mathrm{N}\right)$ in summer and lower insolation $\left(-5 \%\right.$ at $\left.45^{\circ} \mathrm{N}\right)$ in the winter, while ice-sheet extent and trace gas concentrations were similar to modern-day pre-industrial values (Bonfils et al., 2004). The MH is also a period rich in palaeoecological records (Wanner et al., 2008), providing the spatial coverage suitable for continental-scale data-model comparison that is also comparable with the grid-box resolution of climate models (Davis et al., 2003). 
It is for these reasons that the $\mathrm{MH}$ has been the focus of major data-model comparison projects such as the Palaeo Model Intercomparison Project (PMIP) (Joussaume and Taylor, 1995; Masson et al., 1999), and its successors PMIP2 (Braconnot et al., 2007a, b) and PMIP3/CMIP5 (Braconnot et al., 2012), that aim at evaluating climate models and provide a better understanding of climate change and climate feedbacks. Previous data-model comparisons have shown that climate models fail to simulate the summer cooling observed by proxy data over Southern Europe that is contrary to the increase in summer insolation in the $\mathrm{MH}$ (Davis and Brewer, 2009), and the strong winter warming observed over parts of northern Europe (Masson et al., 1999; Bonfils et al., 2004; Brewer et al., 2007) that is also contrary to the decrease in winter insolation in the MH. Nevertheless, models have still been able to demonstrate high-latitude winter warming through the action of local feedbacks such as sea ice and vegetation (Wohlfahrt et al., 2004; Braconnot et al., 2007b; Otto et al., 2009).

Atmospheric circulation has been identified as a significant cause of recent changes in the climate of Europe in both summer and winter (Jones and Lister, 2009; Küttel et al., 2011; Della-Marta et al., 2007; Ionita et al., 2012). In summer, recent extreme warm events such as those that occurred during the summers of 2003 and 2010 (Barriopedro et al., 2011; Black, 2004) were mainly driven by a persistent blocking high-pressure system located over central and eastern Europe which led to stable cloud-free skies and warm air advection from the south (Della-Marta et al., 2007). In the late 20th century, winters in Europe were characterized by a persistent positive phase of the $\mathrm{AO} / \mathrm{NAO}$, which resulted in strengthened westerlies and mild, wet conditions over northern Europe, while southern Europe experienced drier, cooler conditions leading to severe drought in many parts of the Mediterranean (Hurrell et al., 2003).

Based on palaeoclimate reconstructions, previous studies have suggested that Europe may have experienced analogous changes in atmospheric circulation during the MH. Antonsson et al. (2008) showed that anticyclonic conditions over Scandinavia may have accounted for warmer summers reconstructed from pollen records in this region, whilst in winter, many authors have suggested the MH was characterized by a positive AO or NAO (Nesje et al., 2001; Davis and Stevenson, 2007; Rimbu et al., 2004; Davis and Brewer, 2009). Climate model simulations in contrast show little change in winter in the mean-state atmospheric circulation as well as in inter-annual and decadal AO/NAO (Arctic Oscillation, North Atlantic Oscillation) variability during the mid-Holocene (Gladstone et al., 2005; Lu et al., 2010), while changes in atmospheric circulation in summer have not been widely investigated using models (Bonfils et al., 2004; Braconnot et al., 2007a).

Here we investigate the potential role of changes in atmospheric circulation on the $\mathrm{MH}$ climate of Europe based on a new pollen-based reconstruction with a greatly im- proved $6 \mathrm{ka}$ data set compared to previous studies. This includes improvements in the geographical coverage of sites that allow better resolution of the spatial patterns of climatic anomalies associated with changes in atmospheric circulation. We also reconstruct a broader range of climate parameters that includes winter and summer precipitation and temperature change based on a larger and higher-quality modern pollen calibration data set. The role of atmospheric circulation is investigated by comparing reconstructed climate with $\mathrm{MH}$ experiments performed by $14 \mathrm{GCMs}$ as part of the CMIP5/PMIP3 project (Braconnot et al., 2012), and with analogous modern climate anomalies associated with seasonal atmospheric circulation modes over Europe.

\section{Methods}

Our climate reconstruction is based on an updated fossil and modern pollen data set compiled from the European Pollen Database (EPD) (Fyfe et al., 2009; Davis et al., 2013), the PANGAEA data archive, and digitized and raw count data from other sources (Collins et al., 2012). European MH climate was reconstructed at each site using a PFT-based Modern Analogue Technique following Davis et al. (2003) based on a training set of 4174 modern pollen samples and 4287 mid-Holocene samples from 756 sites. This data set represents a substantial improvement compared with data sets used in previous data-model comparisons. Our fossil pollen data set includes $48 \%$ more sites compared with Davis et al. (2003) and used by Brewer et al. (2007), and $143 \%$ more sites compared to Cheddadi et al. (1997), with this improvement in data coverage spread throughout Europe (Fig. 1). The modern pollen data set has $81 \%$ more sites compared with Davis et al. (2003) and $221 \%$ more sites compared with Cheddadi et al. (1997). Following Davis et al. (2003), we only used sites with chronologies based on radiometric or other independent dating (Giesecke et al., 2013). This contrasts with most previous studies (Huntley and Prentice, 1988; Guiot et al., 1993; Cheddadi et al., 1997; Wu et al., 2007; Bartlein et al., 2010) which have relied heavily on the data set of Huntley and Birks (1983) where around $35 \%$ of the sites had no $14 \mathrm{C}$ dates or other independent dating control (Guiot et al., 1993). In addition to existing data quality checks on the surface sample training set (Davis et al., 2013) we also undertook a further check on the geo-referencing using a high-resolution digital elevation model (DEM) (Jarvis et al., 2008). Uncertainty in the geo-referencing was identified as unacceptable where the altitude for the site given in the metadata differed by greater than $250 \mathrm{~m}$ from that suggested by the latitude and longitude, leading to the exclusion of 440 sites from the Davis et al. (2013) data set.

The reconstructed climate anomalies for each of the fossil sites were calculated using the R package "rioja" (Juggins, 2013) then interpolated onto a uniform spatial grid using a 4-D thin plate spline from the R package "fields" 


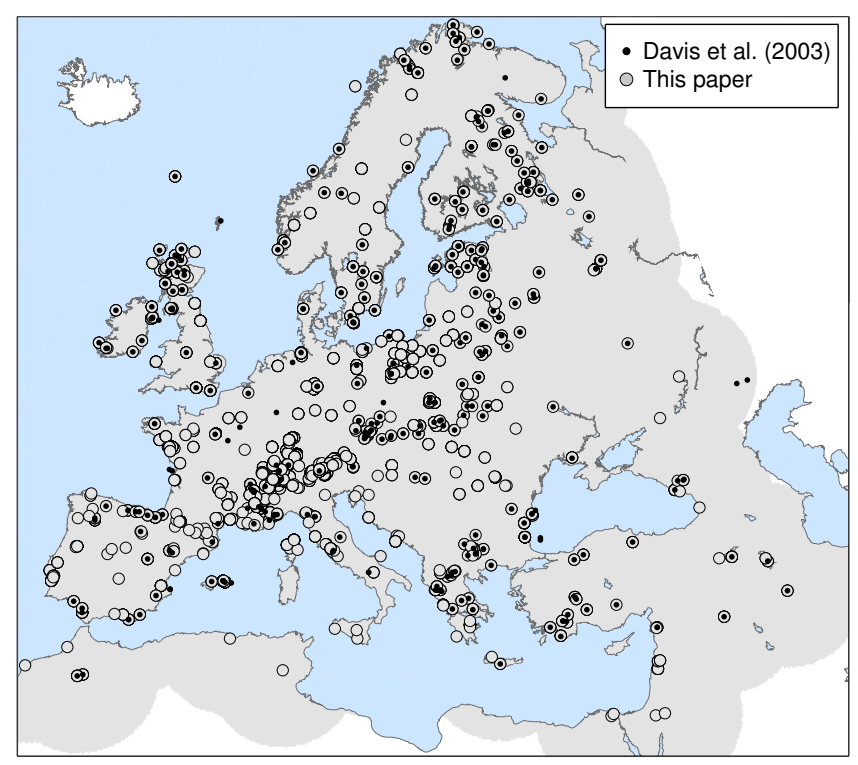

Figure 1. Spatial distribution of pollen sites (open circles) used to reconstruct the climate for the mid-Holocene. The number of sites analysed represents an increase of $48 \%$ compared to Davis et al. (2003) (black dots). Interpolated climate values were limited to a distance of $500 \mathrm{~km}$ from the pollen site location (grey area).

(Fields Development Team, 2006), as also used by Davis et al. (2003). This method interpolates through time on to the chosen time slice $(6000 \mathrm{BP})$, reducing the problem of temporal "blurring" associated with traditional methods that integrate all the samples within a wide time window, for instance $6000 \mathrm{BP} \pm 500$ years (e.g. Cheddadi et al., 1997). The latter time window approach can result in samples being treated as concurrent, when in fact they can be up to 1000 years distant from each other and up to 500 years from the target time. Using our 4-D method, we reconstructed the climate parameters of summer and winter temperatures and precipitation that have been widely used in previous pollen-climate studies (Bartlein et al., 2010). An evaluation of the climate reconstruction method based on $n$-fold leave-one-out crossvalidation is shown in Table 1. This shows that our transfer function has robust skill in all parameters, although winter precipitation is significantly weaker than the other parameters. This can be attributed to the difficulty of reconstructing winter precipitation from areas where much of the precipitation falls as snow, such as northern Europe. However, comparisons with other reconstructions of winter precipitation based on other proxies from sites in northern Norway and Germany over the Holocene show good agreement (Mauri et al., 2014).

Uncertainties in our gridded reconstruction were calculated as a combination of (1) the standard error of the combined uncertainty of the samples within each grid square (Bartlein et al., 2010), and (2) the standard error of the interpolation (Fields Development Team, 2006). We also applied
Table 1. Performance of the pollen-climate transfer function based on $n$-fold leave-one-out cross-validation. For each climate variable we report the coefficient of determination $\left(r^{2}\right)$, the root mean square error (RMSE) and the actual error (Birks and Seppa, 2004).

\begin{tabular}{lrrr}
\hline $\begin{array}{l}\text { Climate } \\
\text { parameter }\end{array}$ & $\begin{array}{r}\text { Correlation } \\
\left(r^{2}\right)\end{array}$ & RMSE & Uncertainty \\
\hline$T_{(\mathrm{DJF})}$ & 0.85 & 2.78 & $\pm 1.67^{\circ} \mathrm{C}$ \\
$P_{(\mathrm{DJF})}$ & 0.49 & 28.8 & $\pm 5.37 \mathrm{~mm} \mathrm{month}^{-1}$ \\
$T_{(\mathrm{JJA})}$ & 0.71 & 2.59 & $\pm 1.61^{\circ} \mathrm{C}$ \\
$P_{(\mathrm{JJA})}$ & 0.78 & 17.6 & $\pm 4.20 \mathrm{~mm} \mathrm{month}^{-1}$ \\
\hline
\end{tabular}

an interpolation limit of $500 \mathrm{~km}$ from the nearest data point, which represents a conservative boundary compared to the $1500 \mathrm{~km}$ limit established by Davis et al. (2003) for pollenbased climate reconstructions. Maps of uncertainty for the reconstructions are shown in Fig. 2 and indicate that uncertainties are generally lowest in areas with high site/sample density such as central Europe, and are highest where site/sample density is lowest such as in the far south and east of the study area.

We compare our climate reconstruction with the results of MH experiments performed by 14 different GCMs as part of the PMIP3/CMIP5 project. The GCMs consist of nine fully coupled Ocean-Atmosphere (OA) models and five fully coupled Ocean-Atmosphere-Carbon (OAC) models (Table 2). In this paper we primarily compare our data-based reconstruction with the multi-model ensemble mean, which we believe provides the best illustration of general model behaviour (IPCC, 2013).

Modern teleconnection indices for the winter $\mathrm{AO}$ and the summer Scandinavian pattern (SCAND) were taken from NOAA (2011) based on Thompson and Wallace (1998) and Barnston and Livezey (1987) respectively.

The SCAND (also known as EU1 in Barnston and Livezey, 1987 ) is defined as the pressure gradient between Scandinavia and secondary areas extending from southwestern $\mathrm{Eu}-$ rope through to eastern Russia and western Mongolia. A negative/positive SCAND is associated with lower/higher pressure over Scandinavia and western Russia, and higher/lower pressure in the surrounding secondary regions. A positive phase of the SCAND in summer usually results from a blocking anticylone over Scandinavia and western Russia resulting in warmer and drier conditions over Scandinavia and a southwards shift of the storm tracks accompanied by higher precipitation rates and lower temperatures over southern Europe (Fig. 3). Some authors have noted the limited nature of the SCAND teleconnection in summer when mid-latitude atmospheric circulation is at its weakest (Bueh and Nakamura, 2007), but others have found that it nevertheless has a significant effect on surface climate (Ionita et al., 2012; MaciasFauria et al., 2012). 
Table 2. Details of the 14 PMIP3/CMIP5 GCMs. Model types are either Ocean-Atmosphere (OA) or Ocean-Atmosphere-Carbon (OAC).

\begin{tabular}{llllll}
\hline & & \multicolumn{2}{c}{ Resolution (lat, long, layers) } & & \\
\cline { 3 - 4 } Model & Type & Atmosphere & Ocean & Years & Institution \\
\hline BCC-CSM1-1 & OAC & 64,128, L26 & 232,360, L40 & 100 & BCC, China \\
CNRM-CM5 & OA & 128,256, L31 & 292,362, L42 & 200 & CNRM-CERFACS, France \\
CSIRO-Mk3-6-0 & OA & 96,192, L18 & 189,192, L31 & 100 & CSIRO-QCCCE, Australia \\
CSIRO-Mk3L-1-2 & OA & 56,64, L18 & 128,224, L21 & 100 & CSIRO, Australia \\
FGOALS-g2 & OA & 60,128, L26 & 196,360, L30 & 100 & LASG-CESS, China \\
FGOALS-s2 & OA & 108,128, L26 & 196,360, L30 & 100 & LASG-IAP, China \\
HadGEM2-CC & OAC & 145,192, L60 & 216,360, L40 & 102 & MOHC, UK \\
HadGEM2-ES & OAC & 145,192, L38 & 216,360, L40 & 35 & MOHC, UK \\
IPSL-CM5A-LR & OAC & 96,96, L39 & 149,182, L31 & 500 & IPSL, France \\
MIROC-ESM & OAC & 64,128, L80 & 192,256, L44 & 100 & MIROC, Japan \\
MRI-CGCM3 & OA & 160,320, L48 & 360,368, L51 & 100 & MRI, Japan \\
CCSM4 & OA & 192,288, L26 & 320,384, L60 & $1 \times 301$ & NCAR, USA \\
& & & & $+1 \times 30$ & \\
GISS-E2-R & OA & 90,144, L40 & 90,144, L32 & $2 \times 100$ & NASA-GISS, USA \\
MPI-ESM-P & OA & 96,192, L47 & 220,256, L40 & $2 \times 100$ & MPI-M, Germany \\
\hline
\end{tabular}
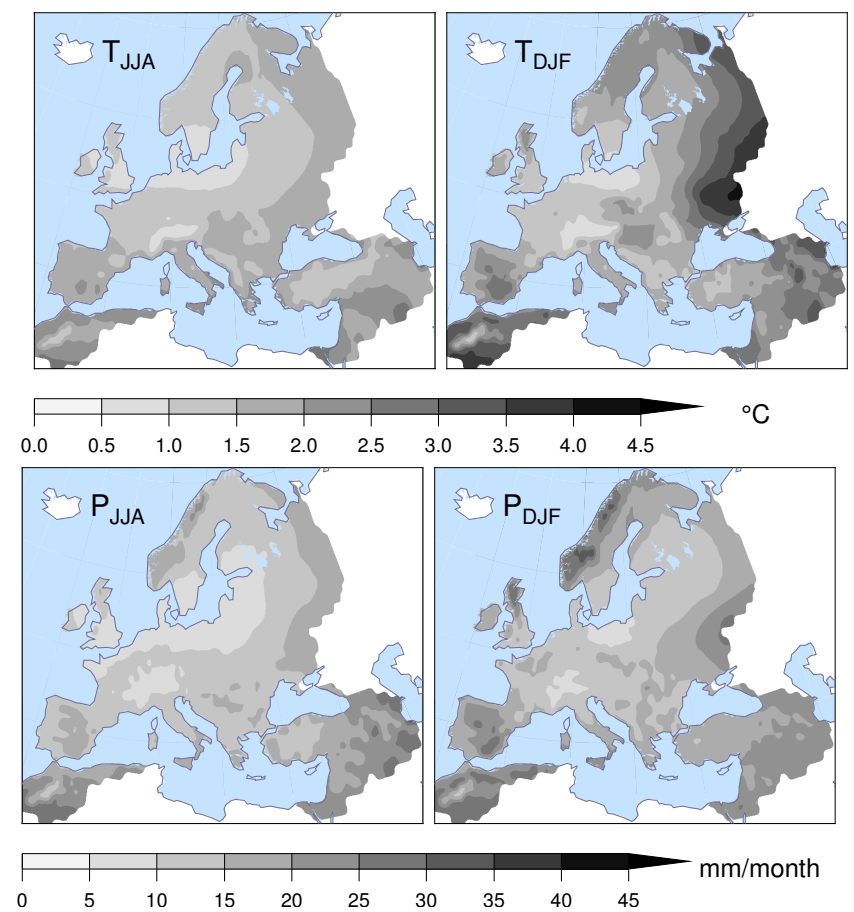

Figure 2. Uncertainties (standard error) associated with the midHolocene data based climate reconstructions shown in Figs. 4-9. These are based on the combined uncertainty of the interpolation and the pollen-climate transfer function (see methods).

The AO index is defined as the pressure gradient between polar and mid-latitude regions, with a negative/positive phase reflecting higher/lower pressure over the poles and lower/higher pressure over the mid-latitudes. In general, a positive phase means a stronger pressure gradient and a stronger zonal (westerly) circulation resulting in warmer and
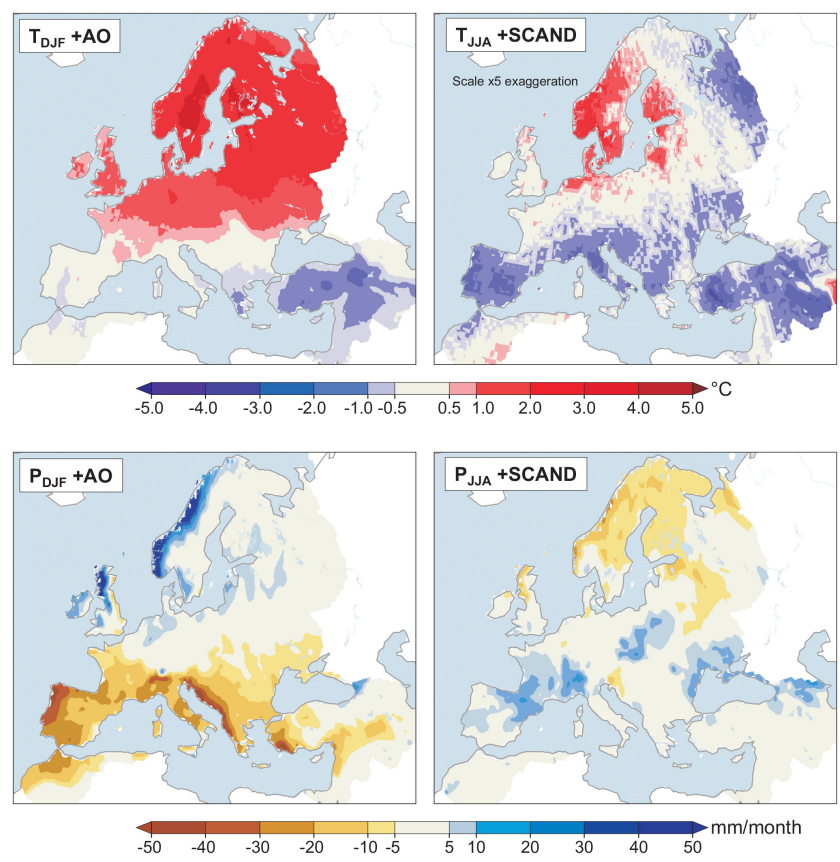

Figure 3. Modern temperature and precipitation anomalies associated with a positive Arctic Oscillation (AO) in winter and Scandinavian pattern (SCAND) in summer. Note that the SCAND temperature is scaled with a $\times 5$ exaggeration. These anomalies were calculated over the 1950-2000 period based on the mean of the years falling in the upper quartile of the teleconnection index.

wetter conditions over northern Europe and cooler and drier conditions over southern Europe (Fig. 3). The AO is closely related to the NAO, which we consider here as the regional manifestation of the $\mathrm{AO}$, although the exact relationship is subject to some debate (Ambaum et al., 2001). 

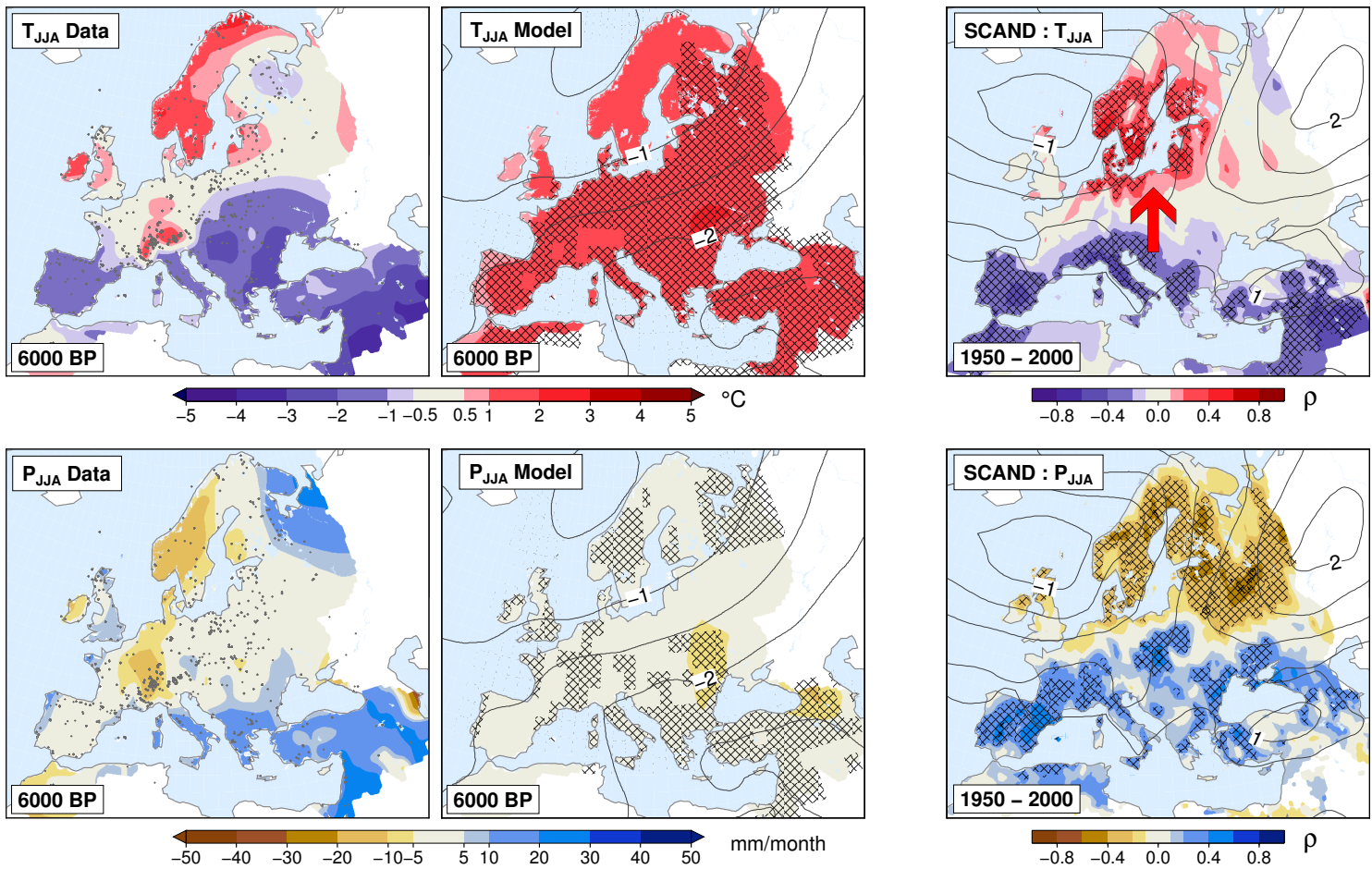

Figure 4. Summer temperature (upper panels) and precipitation (lower panels) as reconstructed from pollen data (left) and simulated (centre) by CMIP5/PMIP3 climate models represented here by the ensemble mean of 14 models. The cross-hatching indicates areas where the differences between the data and model ensemble mean exceed the uncertainties of the reconstruction as shown in Fig. 2. Also shown (right) is the correlation coefficient between modern climate and the SCAND teleconnection index for the period 1950-2000. The cross-hatching indicates areas where the correlation is significant ( $t$ test, $p=0.05$, taking into account serial correlation). Isobars represent surface pressure anomalies (mbar) associated with the mid-Holocene simulations and positive SCAND. A positive SCAND leads to a southerly airstream (large arrow) bringing warmer and drier conditions to Scandinavia, while southern Europe is cooler and wetter. Palaeoclimate data were interpolated to the same grid resolution as the model. Black crosses represent pollen sites used to reconstruct the climate.

The effects of the AO and SCAND on modern temperature, precipitation and pressure over Europe were calculated from NCEP/NCAR Reanalysis data (Kalnay et al., 1996). Modern climate anomalies were calculated with respect to the long-term average for the period 1950-2000.

\section{Results}

\subsection{Summer}

A common feature of climate model simulations for the $\mathrm{MH}$ is a relatively uniform summer warming across the Northern Hemisphere extra-tropics (Braconnot et al., 2004, 2007b, Harrison, 2013). We also find this warming in the PMIP3/CMIP5 ensemble mean in Europe (Fig. 4) and as a robust feature in almost all of the 14 GCMs which all show little if any summer cooling (Fig. 5). In contrast, our reconstructed summer temperatures show a more complex pattern, with warming generally over the north of Europe and particularly over central Scandinavia, while large areas of Southern Europe show cooler conditions. This pattern of summer warming over the north and cooling over the south has also been shown in all previous summer temperature reconstructions using pollen data, including Davis et al. (2003), Huntley and Prentice (1988) and Wu et al. (2007). Summer precipitation in the model ensemble shows relatively little change except for some drier conditions in Eastern Europe, although individual models show much greater variability (Fig. 6). Our reconstruction also shows much greater variability in precipitation change than the model ensemble, with drier conditions occurring roughly in a line from central southern Scandinavia to the western Mediterranean, but with wetter conditions mainly to the east.

\subsection{Winter}

As with summer precipitation, winter temperature anomalies in the MH model ensemble show little change across Europe (Fig. 7), although this partly reflects a balance between some individual models that show warming whilst others show cooling (Fig. 8). At the Northern Hemisphere scale, the slight warming over the far north of Europe in the ensemble is part of a strong warming response over the Barents Sea, whilst a slight cooling to the south reflects a more general 


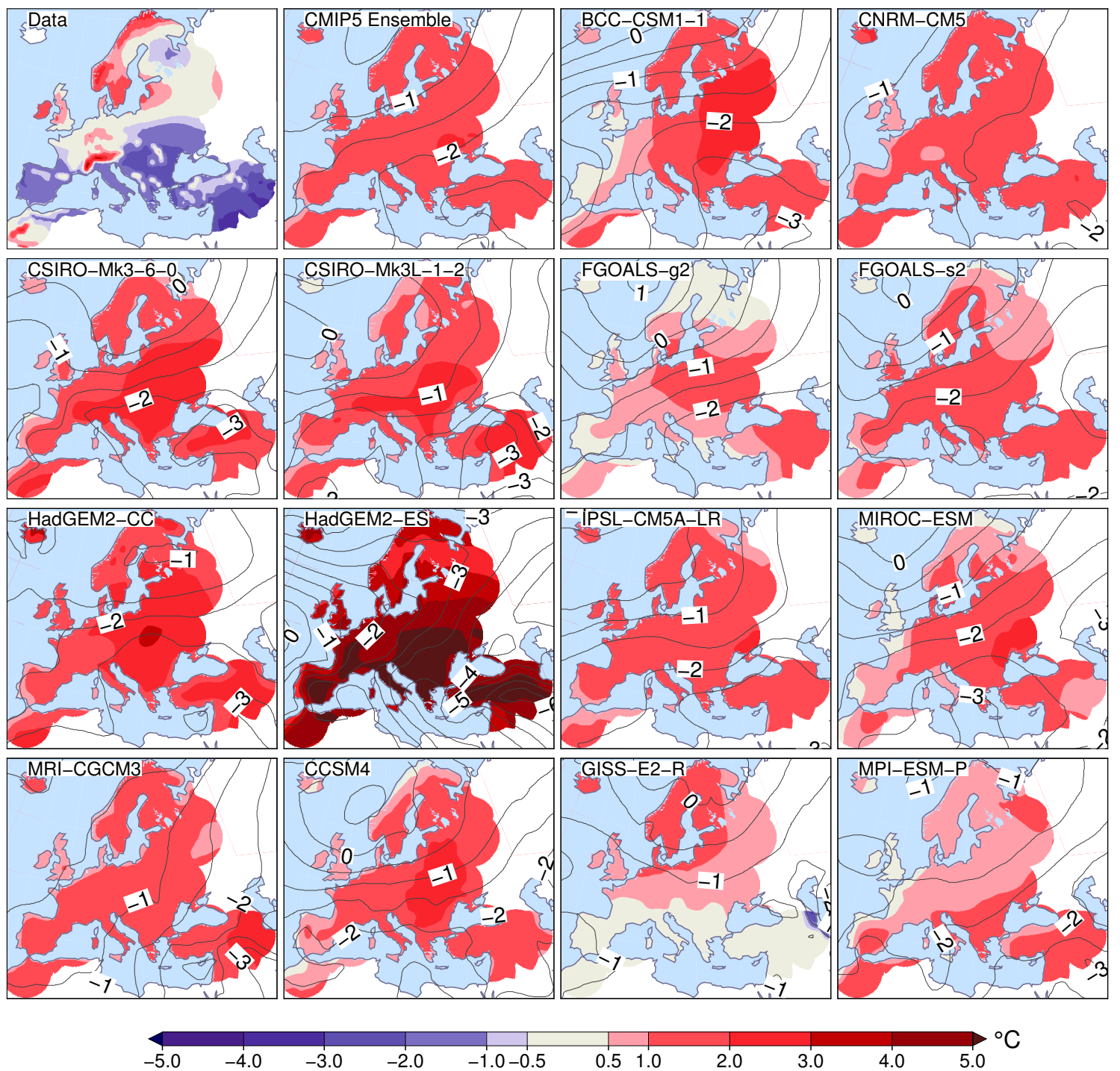

Figure 5. Results of all of the 14 PMIP3/CMIP5 mid-Holocene GCMs showing summer temperature $\left({ }^{\circ} \mathrm{C}\right)$ and pressure (mbar) anomalies.

cooling over lower mid- and tropical latitudes, both of which are typical of PMIP3/CMIP5 and earlier models (Braconnot et al., 2004; Harrison et al., 2013). Neither the ensemble nor individual PMIP3/CMIP5 models show the pattern of winter temperature anomalies shown by the reconstruction, which indicates a more extensive and relatively strong warming extending over much of northern and central Europe, together with a strong but somewhat less extensive cooling over southern Europe. This pattern of high-latitude warming and low-latitude cooling is comparable with previous midHolocene winter temperature reconstructions (Cheddadi et al., 1997; Brewer et al., 2007; Wu et al., 2007). Precipitation changes in winter in the model ensemble are limited, as it is in all of the model simulations (Fig. 9). The data in contrast show more significant changes in winter precipitation than the models, with wetter conditions over Central Europe and eastern Scandinavia, whilst northeastern Iberia and the Middle East show drier conditions.

\section{Discussion}

\subsection{Summer}

The warmer and mainly drier summer climate shown in the model ensemble can be attributed to a direct thermal response to the increase in summer insolation across Europe during the MH (Braconnot et al., 2004). This simple direct response to top-of-the-atmosphere change in solar energy results in a relatively uniform summer warming across all latitudes of Europe in model simulations, while reconstructed summer temperatures indicate a more complex pattern of regional warming and cooling (Fig. 4). It has been suggested 


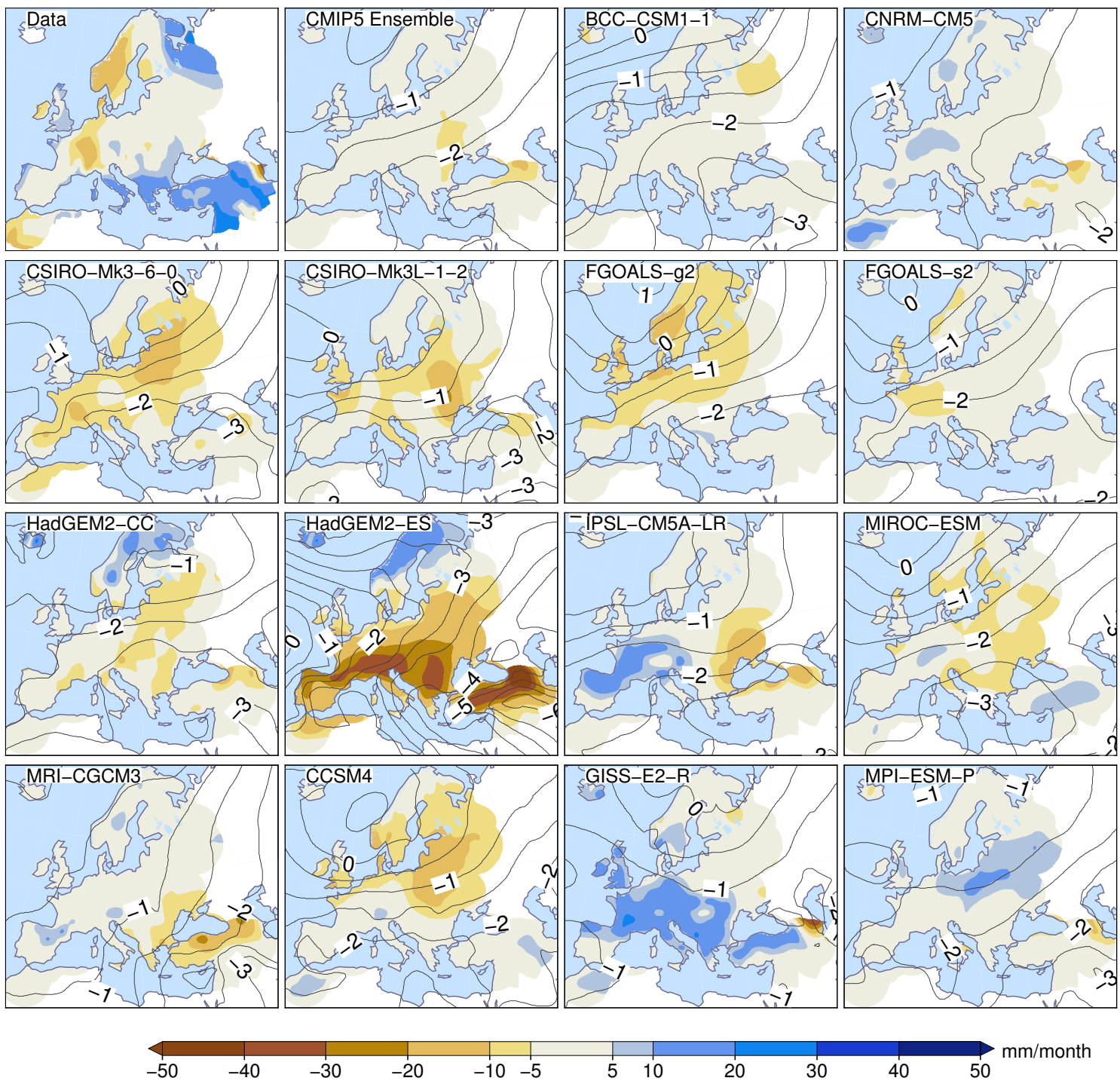

Figure 6. As for Fig. 5 but showing summer precipitation anomalies (mm month ${ }^{-1}$ ).

(Antonsson et al., 2008; Seppa and Birks, 2001) that warmer and drier conditions during the MH over Scandinavia were the result of anticyclonic blocking over Northern Europe leading to warm air advection from southern latitudes and clear skies that promoted radiative heating. This is also consistent with isotopic evidence from lake sediments that suggest a more meridional circulation over Scandinavia in the MH associated with anticyclonic blocking (Jonsson et al., 2010).

One of the most common teleconnection patterns for this type of blocking is a positive or high index phase of the SCAND pattern, which causes warming over central Scandinavia as well as cooling over southern Europe. The pattern of climate anomalies generated by this pressure pattern is very similar to that observed over Europe during the $\mathrm{MH}$, suggesting that anticyclonic blocking provides a plausible ex- planation for the MH summer climate not just over northern Europe but also southern Europe. Climate model simulations however do not reproduce this kind of high-pressure blocking pattern, where modelled pressure anomalies indicate a decrease, not increase, in atmospheric pressure over continental Europe (Figs. 4-6). A dynamic explanation for the cooling observed over Southern Europe in the data in summer differs from that proposed by Bonfils et al. (2004) who suggest cooling may be the result of a greater proportion of the radiative energy being released as latent heat due to increased winter soil moisture. This may indeed be a factor, but evidence of low water levels in groundwater-fed lakes in Spain suggests decreased (not increased) winter recharge in the MH in southern Europe (Davis and Stevenson, 2007), consistent with our pollen-based reconstruction which also shows drier winters across much of the region. Dry winters and resulting 

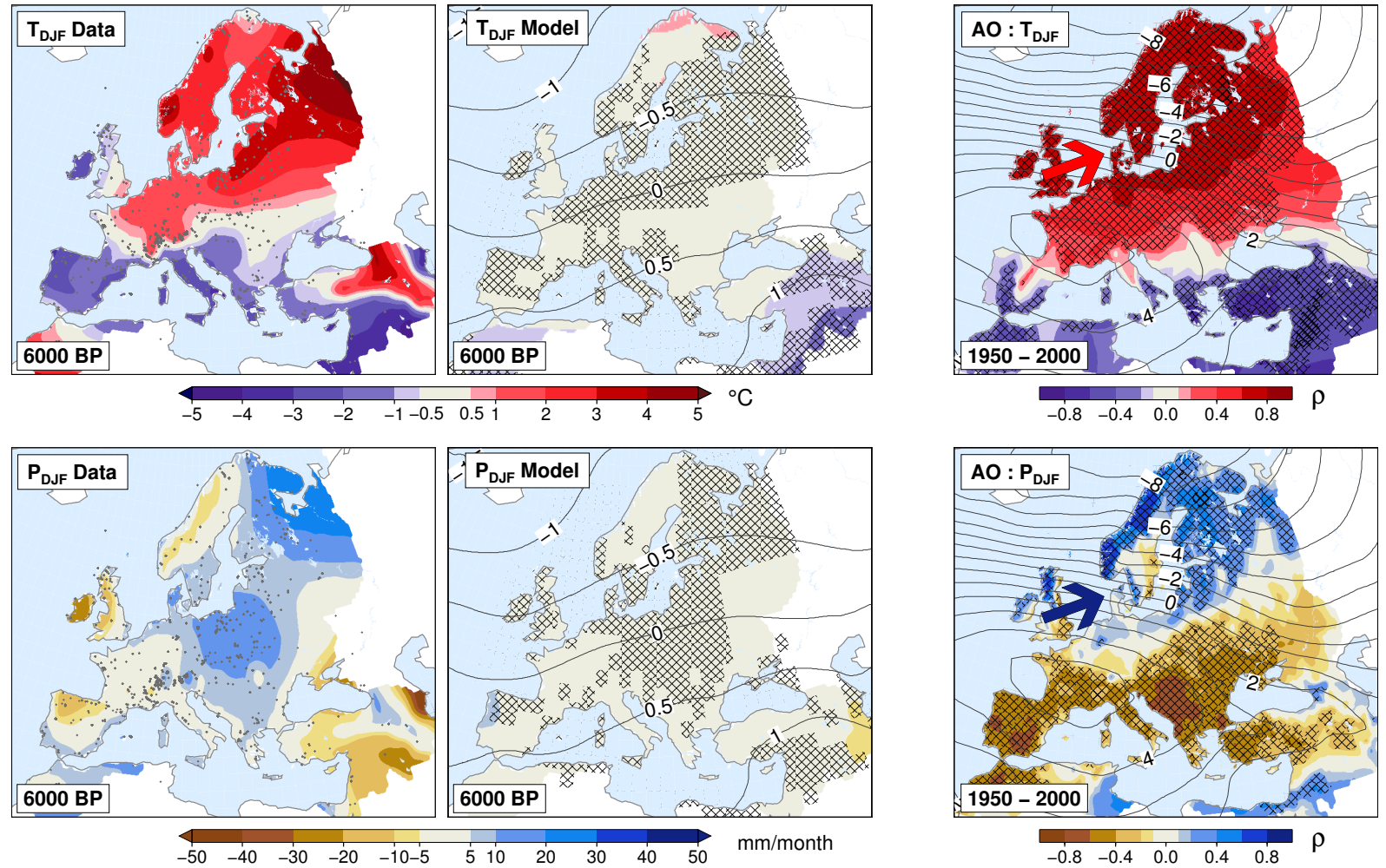

Figure 7. As for Fig. 4, but for winter and using the Arctic Oscillation (AO) teleconnection index. A positive AO leads to stronger westerly winds bringing warmer (large red arrow) and wetter (large blue arrow) conditions over northern Europe, whilst southern Europe experiences relatively cooler and drier conditions.

soil moisture deficits over southern Europe in spring have also been identified as one of the factors in promoting summer heat waves over northern Europe (García-Herrera et al., 2010).

\subsection{Winter}

Modern inter-annual variability of the winter climate of Europe is largely a function of the AO (regionally expressed as the NAO) teleconnection pattern, which influences the strength and position of the westerly atmospheric circulation and accompanying storm track (Hurrell et al., 2003). A number of authors have suggested that the AO/NAO was in a positive or high index phase during the $\mathrm{MH}$ based on Holocene temperature gradients across Europe (Davis and Brewer, 2009), water levels in groundwater-fed lakes in the Mediterranean (Davis and Stevenson, 2007), the distribution of Arctic driftwood (Funder et al., 2011), the mass-balance of Norwegian glaciers (Nesje et al., 2001), and the pattern of Atlantic sea surface temperatures (Rimbu et al., 2004). Strong westerly winds such as those experienced under a positive AO/NAO were also proposed by Vork and Thomsen (1996) to explain the occurrence of thermophilious Mediterranean ostracods around the coast of Denmark in the MH, as well as by Harff et al. (2011) to explain the elevated salinity of the Baltic Sea at this time. The study by Vork and Thomsen (1996) suggested that winter sea surface temperatures were around $5-6{ }^{\circ} \mathrm{C}$ above present around Denmark in the $\mathrm{MH}$ in order to explain the observed ostracod fauna, supporting our reconstruction of much higher than present winter temperatures over northern Europe at this time.

Model simulations of $\mathrm{MH}$ climate based on the earlier PMIP2 GCMs showed little change in AO (Lu et al., 2010), with just a few models showing only a weak shift to a positive phase of the NAO (Gladstone et al., 2005; Fischer and Jungclaus, 2011). Felis et al. (2004) also show a shift to a more positive AO/NAO in a model simulation of the last Interglacial, but the level of winter warming over central Europe shown in this simulation is not shown in other simulations using other models (Lunt et al., 2013; Otto-Bliesner et al., 2013). This is also consistent with the latest PMIP3/CMIP5 models shown here for the $\mathrm{MH}$, which generally indicate a decrease in pressure over Iceland and increase in pressure to the south equivalent to a positive $\mathrm{AO} / \mathrm{NAO}$, but of insufficient strength to translate into a strong westerly circulation over northern Europe (Figs. 7-9). The winter warming shown in a few models over northern Europe appears to be the result of alternative mechanisms such as sea-ice feedbacks in the Barents Sea area (Fischer and Jungclaus, 2011), or the release in winter of sensible heat over Europe as a result 


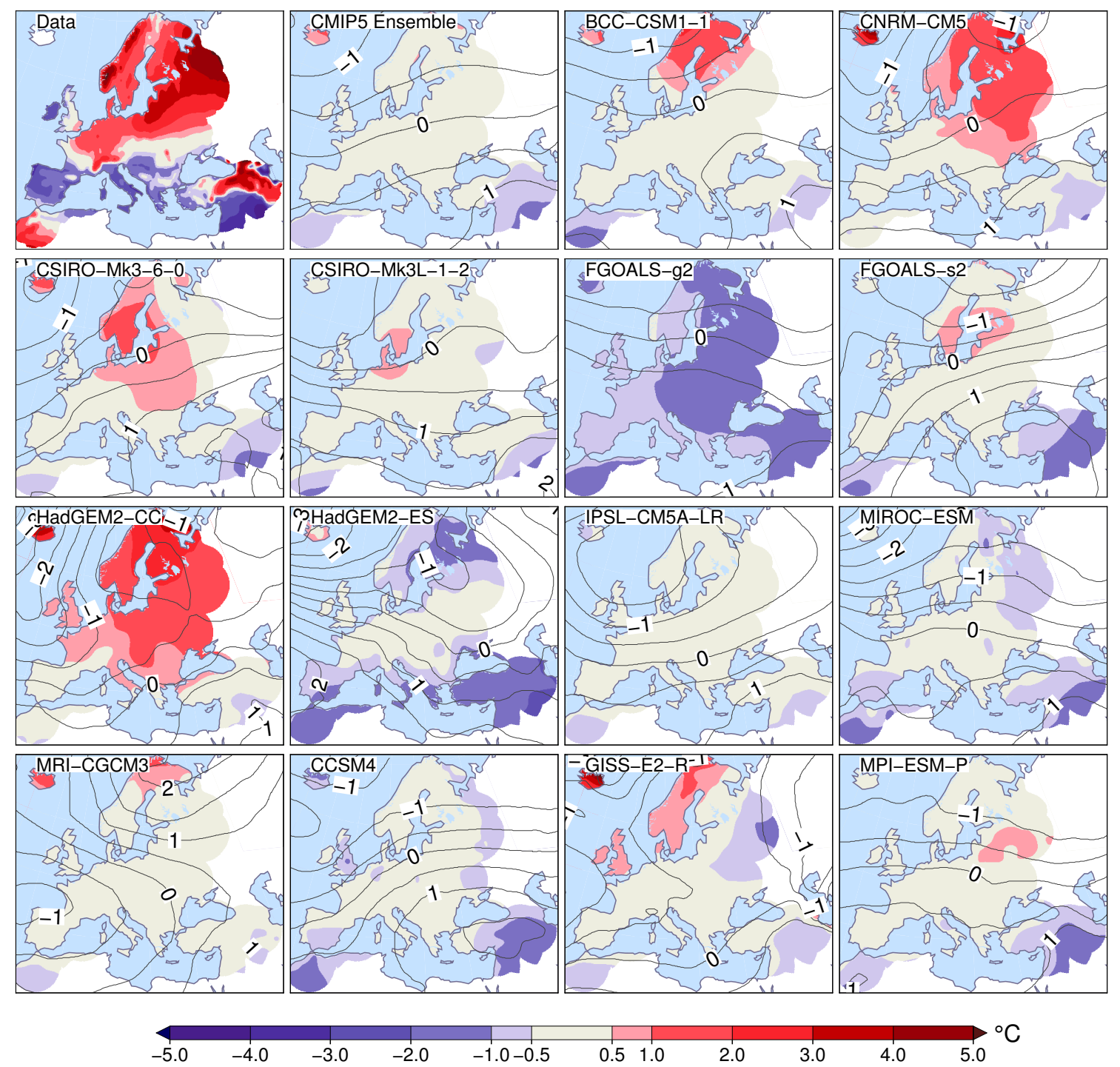

Figure 8. Results of all of the 14 PMIP3/CMIP5 mid-Holocene GCMs showing winter temperature $\left({ }^{\circ} \mathrm{C}\right)$ and pressure (mbar) anomalies.

of warmer summer land and sea temperatures. This warming over northern Europe is also different from that shown in the data because it is not accompanied by substantial cooling over southern Europe and the Middle East (Fig. 8). This cooling is indicative of a strong positive $\mathrm{AO} / \mathrm{NAO}$, which advects warmer and wetter maritime air from the west and south over a large area of northern Europe, while at the same time cooler and drier air is advected from the north and east over southern Europe (Fig. 7). A somewhat limited cooling over southern Europe is also shown in the model ensemble, but in this case it can be attributed to the decrease in winter insolation across the mid- and lower latitudes of the Northern Hemisphere at this time which results in a general cooling over these areas in most model simulations (Davis and Brewer, 2009; Harrison et al., 2013). Reconstructed precipitation anomalies are also consistent with a positive $\mathrm{AO} / \mathrm{NAO}$, showing wetter condi- tions over northern Europe and drier conditions over southern Europe. This is also different from the few model simulations which show winter warming over northern Europe, where this warming in contrast was not accompanied by wetter conditions.

\subsection{The atmospheric circulation}

Many of the recent and historical periods of climatic warming in Europe have been explained by changes in atmospheric circulation. For instance, much of the warming that occurred in the late 20th century in Europe has been attributed to the increased number of winters with a high-index AO/NAO (Hurrell, 1995; Visbeck et al., 2001). High-index AO/NAO conditions are also thought to have occurred during the Medieval Climate Anomaly, providing a dynamic explanation for the winter warmth experienced over Europe at this time 


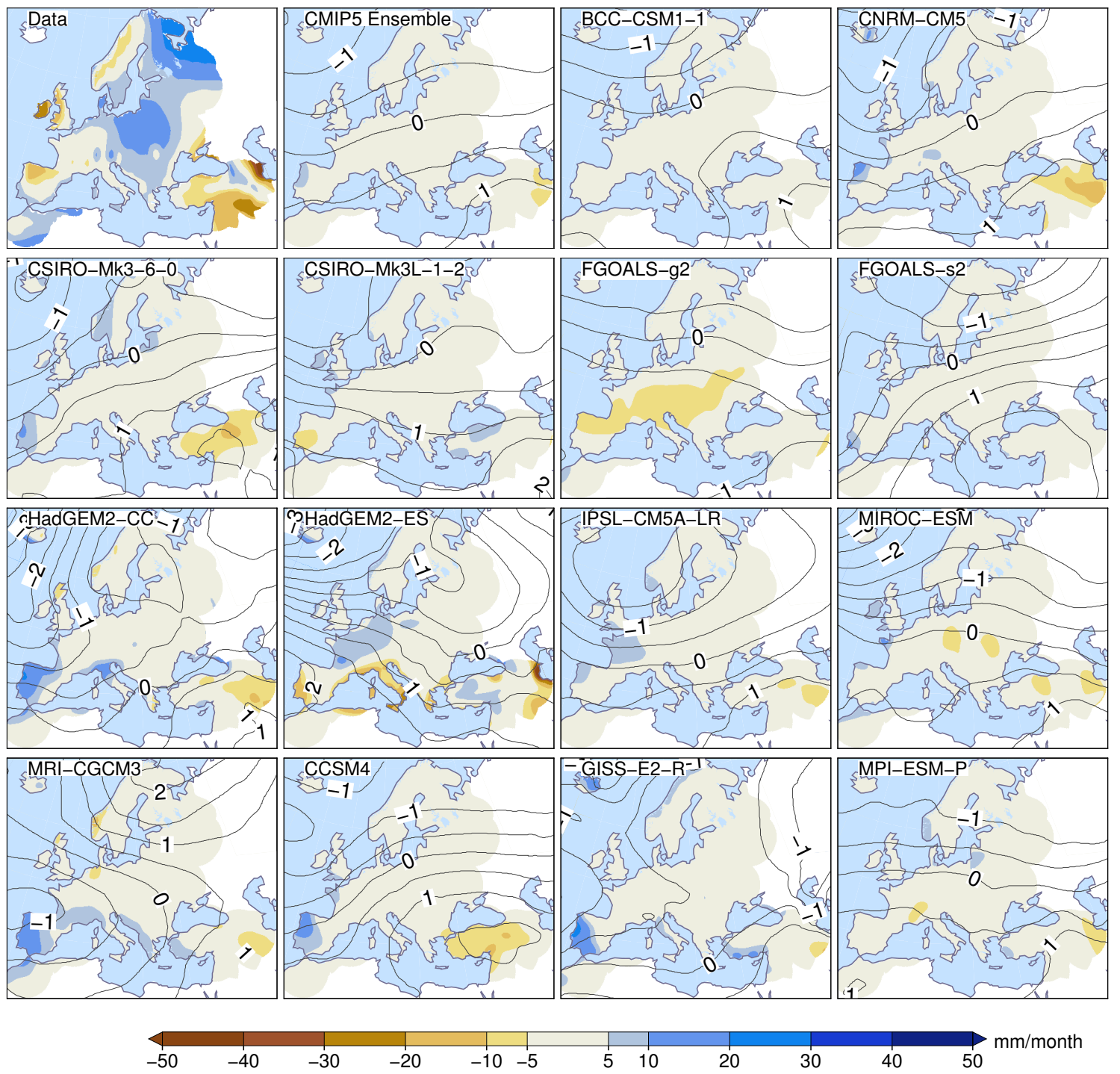

Figure 9. As for Fig. 8, but showing winter precipitation anomalies (mm month ${ }^{-1}$ ).

(Trouet et al., 2009). Similarly in summer, the increased occurrence of heat waves in recent years has been shown to be the result of anomalous atmospheric circulation associated with blocking anticyclones (Kysely and Huth, 2006). This pattern has also been shown to underlie summer warming on longer timescales in the late Holocene (Della-Marta et al., 2007; Trouet et al., 2012; Yiou et al., 2012).

Changes in atmospheric circulation have a significant influence on European climate (Sepp and Jaagus, 2002; van Ulden and van Oldenborgh, 2006; Hoy et al., 2013), but many climate models have difficulty reproducing this aspect of modern climate (van Ulden and van Oldenborgh, 2006; Woollings, 2010; Kjellstrom et al., 2011; Brands et al., 2013). The warming in Europe during the mid-Holocene simulated in climate models differs fundamentally from that shown in the data, and indicates a high sensitivity in models to the ef- fects of the amplified seasonal insolation cycle experienced at this time, showing greater warming (cooling) in summer (winter) in response to increased (decreased) summer (winter) insolation. Our reconstructed climate in contrast shows a greater warming in winter than in summer at the European scale, and a spatial pattern of anomalies that is more consistent with changes in atmospheric circulation rather than simple direct radiative forcing by insolation. This suggests a greater role for atmospheric dynamics in explaining interglacial warming, and a challenge to traditional ideas about the simple role of Northern Hemisphere high-latitude summer insolation in driving interglacial climates (Milankovitch, 1941). The greater importance of winter over summer warming could lend support to the role of the winter latitudinal insolation gradient in driving interglacial warming, having an identical orbital signature to summer insolation, and 
which could influence the atmospheric circulation through its control of the latitudinal temperature gradient (Davis and Brewer, 2009, 2011).

\section{Conclusions}

We have presented a new seasonal (summer and winter) gridded temperature and precipitation reconstruction for Europe during the $\mathrm{MH}$, based on a fossil pollen and modern pollen data set that is greatly improved in both size and quality compared with previous studies. This climate reconstruction has been compared with the latest PMIP3/CMIP5 GCM simulations and with the modern winter $\mathrm{AO} / \mathrm{NAO}$ and summer SCAND that represent potential analogues of modes of climate variability connected with atmospheric circulation during the $\mathrm{MH}$.

Our data-model comparison highlights significant differences between the reconstruction and the model simulations. We explain these differences in terms of atmospheric circulation, which appears strongly imprinted on the reconstructed climate, but subsumed in climate models in favour of a simple direct radiative response to the change in the amplitude of the seasonal insolation cycle. We suggest that the MH climate of Europe was characterized by a strong zonal circulation in winter consistent with a present-day positive or high index AO/NAO teleconnection. This brought milder wetter conditions into northern Europe and cooler drier conditions to many parts of southern Europe. In summer, we suggest that the zonal circulation was weak, and that anti-cyclonic blocking occurred close to Scandinavia, comparable with a positive or high index SCAND teleconnection. This caused a more meridional circulation, which brought clear skies and dry and warm conditions to northern Europe, but relatively cooler and somewhat wetter conditions to many parts of southern Europe. Both of these seasonal changes in atmospheric circulation have been suggested by previous authors, and particularly in the case of the winter $\mathrm{AO} / \mathrm{NAO}$, are supported by a large number of studies based on many different proxies (Vork and Thomsen, 1996; Nesje et al., 2001; Rimbu et al., 2004; Davis and Stevenson, 2007; Davis and Brewer, 2009; Jonsson et al., 2010; Funder et al., 2011). Here we have provided evidence that the changes in atmospheric circulation suggested by these studies for the mid-Holocene can also explain the pattern of winter and summer temperature and precipitation anomalies across Europe at this time. These mutually supporting convergent lines of evidence also provide support for the reliability of our reconstruction, and particularly in those areas where we show large transfer-function uncertainties but which nevertheless conform to the pattern of expected circulation anomalies.

Evidence that climate models may have difficulty simulating $\mathrm{MH}$ atmospheric circulation is consistent with similar model deficiencies found on contemporary timescales, and may be important in understanding why Europe has recently been warming faster than predicted (van Oldenborgh et al., 2009). It also suggests that the atmospheric circulation may be more important in driving interglacial warming than previously considered based on model experiments that appear too sensitive to direct insolation forcing. Future work will extend this $\mathrm{MH}$ reconstruction to the complete Holocene, and investigate this problem by comparing this climate record with transient Holocene model simulations.

Acknowledgements. In using the PMIP3/CMIP5 model simulations we acknowledge the World Climate Research Programme's Working Group on Coupled Modelling, which is responsible for CMIP, and we thank the climate modelling groups (listed in Table 2 of this paper) for producing and making available their model output. For CMIP the US Department of Energy's Program for Climate Model Diagnosis and Intercomparison provides coordinating support and led development of software infrastructure in partnership with the Global Organization for Earth System Science Portals.

The authors would like to thank Steve Juggins for the rioja software used to make the pollen-climate reconstruction and Daniele de Rigo for help with statistical analysis, and acknowledge the resources provided by the European Pollen Database and the PANGAEA data archive that provided most of the fossil pollen data used in the reconstruction. Funding for this research was provided by grants from the Swiss National Science Foundation (PP0022_119049) and the Italian Ministry of Research and Education (FIRB RBID08LNFJ).

Edited by: G. Lohmann

\section{References}

Ambaum, M. H. P., Hoskins, B. J., and Stephenson, D. B.: Arctic oscillation or North Atlantic oscillation?, J. Climate, 14, 34953507, 2001.

Antonsson, K., Chen, D., and Seppä, H.: Anticyclonic atmospheric circulation as an analogue for the warm and dry mid-Holocene summer climate in central Scandinavia, Clim. Past, 4, 215-224, doi:10.5194/cp-4-215-2008, 2008.

Barnston, A. G. and Livezey, R. E.: Classification, Seasonality and Persistence of Low-Frequency Atmospheric Circulation Patterns, Month. Weath. Rev., 115, 1083-1126, 1987.

Barriopedro, D. B., D., Fischer, E. M., Luterbacher, J., Trigo, R., and Garcia-Herrera, R.: The Hot Summer of 2010: Redrawing the Temperature Record Map of Europe, Science, 332, 220-224, 2011.

Bartlein, P. J., Harrison, S. P., Brewer, S., Connor, S., S., D. B. A., Gajewski, K., Guiot, J., Harrison-Prentice, T. I., Henderson, A., Peyron, O., Prentice, I. C., Scholze, M., Seppä, H., Shuman, B., Sugita, S., Thompson, R. S., Viau, A. E., Williams, J., and Wu, H.: Pollen-based continental climate reconstructions at 6 and 21 ka: a global synthesis, Clim. Dynam., 37, 3-4, 775-802, 2010.

Birks, H. J. B. and Seppa, H.: Pollen-based reconstructions of lateQuaternary climate in Europe - progress, problems, and pitfalls, Ac. Palaeobot., 44, 317-334, 2004.

Black, E.: Factors contributing to the summer 2003 European heatwave, Weather, 59, 217-223, 2004. 
Bonfils, C., de Noblet-Ducoudre, N., Guiot, J., and Bartlein, P.: Some mechanisms of mid-Holocene climate change in Europe, inferred from comparing PMIP models to data, Clim. Dynam., 23, 79-98, 2004.

Braconnot, P., Harrison, S., Joussaume, J., Hewitt, C., Kitoh, A., Kutzbach, J., Liu, Z., Otto-Bleisner, B. L., Syktus, J., and Weber, S. L.: Evaluation of Coupled Ocean-Atmosphere Simulations of the Mid-Holocene, in: Past Climate Variability through Europe and Africa, edited by: Battarbee, R. W., Gasse, F., and Stickley, C. E., Kluwer Academic Publisher, 515-553, 2004.

Braconnot, P., Otto-Bliesner, B., Harrison, S., Joussaume, S., Peterchmitt, J.-Y., Abe-Ouchi, A., Crucifix, M., Driesschaert, E., Fichefet, Th., Hewitt, C. D., Kageyama, M., Kitoh, A., Laîné, A., Loutre, M.-F., Marti, O., Merkel, U., Ramstein, G., Valdes, P., Weber, S. L., Yu, Y., and Zhao, Y.: Results of PMIP2 coupled simulations of the Mid-Holocene and Last Glacial Maximum Part 1: experiments and large-scale features, Clim. Past, 3, 261277, doi:10.5194/cp-3-261-2007, 2007a.

Braconnot, P., Otto-Bliesner, B., Harrison, S., Joussaume, S., Peterchmitt, J.-Y., Abe-Ouchi, A., Crucifix, M., Driesschaert, E., Fichefet, Th., Hewitt, C. D., Kageyama, M., Kitoh, A., Loutre, M.-F., Marti, O., Merkel, U., Ramstein, G., Valdes, P., Weber, L., Yu, Y., and Zhao, Y.: Results of PMIP2 coupled simulations of the Mid-Holocene and Last Glacial Maximum - Part 2: feedbacks with emphasis on the location of the ITCZ and mid- and high latitudes heat budget, Clim. Past, 3, 279-296, doi:10.5194/cp-3-279-2007, 2007b.

Braconnot, P., Harrison, S., Kageyama, M., Bartlein, J., Masson, V., Abe-Ouchi, A., Otto-Bliesner, B., and Zhao, Y.: Evaluation of climate models using palaeoclimatic data, Nat. Clim. Change, 2, 417-424, doi:10.1038/NCLIMATE1456, 2012.

Brands, S., Herrera, S., Fernandez, J., and Gutierrez, J. M.: How well do CMIP5 Earth System Models simulate present climate conditions in Europe and Africa?, Clim. Dynam., 41, 803-817, doi:10.1007/s00382-013-1742-8, 2013.

Brewer, S., Guiot, J., and Torre, F.: Mid-Holocene climate change in Europe: a data-model comparison, Clim. Past, 3, 499-512, doi:10.5194/cp-3-499-2007, 2007.

Bueh, C. and Nakamura, H.: Scandinavian pattern and its climatic impact, Q. J. Roy. Meteor. Soc., 133, 2117-2131, 2007.

Cheddadi, R., Yu, G., Guiot, J., Harrison, S. P., and Prentice, I. C.: The climate of Europe 6000 years ago, Clim. Dynam., 13, 1-9, 1997.

Collins, P. M., Davis, B. A. S., and Kaplan, J. O.: The mid-Holocene vegetation of the Mediterranean region and southern Europe, and comparison with the present day, J. Biogeogr., 39, 1848-1861, 2012.

Davis, B. A. S., Brewer, S., Stevenson, A. C., and Guiot, J.: The temperature of Europe during the Holocene reconstructed from pollen data, Quaternary Sci. Rev., 22, 1701-1716, 2003.

Davis, B. A. S. and Brewer, S.: Orbital forcing and the role of the Latitudinal Temperature/Insolation Gradient, Clim. Dynam., 32, 143-165, 2009.

Davis, B. A. S. and Brewer, S.: A unified approach to orbital, solar, and lunar forcing based on the Earth's latitudinal insolation/temperature gradient, Quaternary Sci. Rev., 30, 1861-1874, 2011.
Davis, B. A. S. and Stevenson, A. C.: The 8.2 ka event and early-mid Holocene forest, fires, and flooding in the Central Ebro Desert, NE Spain, Quaternary Sci. Rev., 26, 1695-1712, 2007.

Davis, B. A. S., Zanon, M., Collins, P., Mauri, A., Bakker, J., Barboni, D., Barthelmes, A., Beaudouin, C., Birks, H. J. B., Bjune, A. E., Bradshaw, R., Brayshay, B., Brugiapaglia, E., Bunting, J., Connor, S., de Beaulieu, J.-L., Edwards, K., Ejarque, A., Fall, P., Florenzano, A., Fyfe, R., Galop, D., Giardini, M., Giesecke, T., Grant, M. J., Jahns, S., Jankovska, V., Juggin, S., Karmann, M., Karpinska-Kolaczek, M., Kolaczek, P., Kühl, N., Kunes, P., Lapteva, E. G., Leroy, S., Leydet, M., Lopez Saez, J. A., Maizier, F., Matthias, I., Meltsov, V., Mercuri, A. M., Miras, Y., Mitchell, F., Molinari, M., Morris, J., Naughton, F., Nielsen, A. B., Novenko , E., Odgaard, B., Ortu, E., Overballe-Petersen, M., Pardoe, H., Peglar, S. M., Pelankova, B., Pidek, I., Sadori, L., Seppä, H., Severova, E., Shaw, H., Swieta-Musznicka, J., Theuerkauf, M., Tonkov, S., Veski, S., van der Knaap, W. O., van Leeuwen, J., Vermoere, M., Woodbridge, J., Zimny, M., and Kaplan, J.: The European Modern Pollen Database (EMPD) project Veg Hist Archaeobot, 22, 521-530, doi:10.1007/s00334012-0388-5, 2013.

Della-Marta, P. M., Luterbacher, J., von Weissenfluh, H., Xoplaki, E., Brunet, M., and Wanner, H.: Summer heat waves over western Europe 1880-2003, their relationship to large-scale forcings and predictability, Clim. Dynam., 29, 251-275, 2007.

Deser, C., Knutti, R., Solomon, S., and Phillips, A. S.: Communication of the role of natural variability in future North American climate, Nat. Clim. Change, 2, 775-779, 2012.

Felis, T., Lohmann, G., Kuhnert, H., Lorenz, S. J., Scholz, D., Pätzold, J., Al-Rousan, S. A., and Al-Moghrabi, S. M.: Increased seasonality in Middle East temperatures during the last interglacial period, Nature, 429, 164-168, 2004.

Fields Development Team: Tools for Spatial Data: http://www.cgd. ucar.edu/Software/Fields, 2006.

Fischer, N. and Jungclaus, J. H.: Evolution of the seasonal temperature cycle in a transient Holocene simulation: orbital forcing and sea-ice, Clim. Past, 7, 1139-1148, doi:10.5194/cp-7-1139-2011, 2011.

Funder, S., Goosse, H., Jepsen, H., Kaas, E., Kjaer, K. H., Korsgaard, N. J., Larsen, N. K., Linderson, H., Lysa, A., Moller, P., Olsen, J., and Willerslev, E.: A 10000-Year Record of Arctic Ocean Sea-Ice Variability-View from the Beach, Science, 333, 747-750, 2011.

Fyfe, R. M., de Beaulieu, J. L., Binney, H., Bradshaw, R. H. W., Brewer, S., Le Flao, A., Finsinger, W., Gaillard, M. J., Giesecke, T., Gil-Romera, G., Grimm, E. C., Huntley, B., Kuneš, P., Kuhl, N., Leydet, M., Lotter, A. F., Tarasov, P. E., and Tonkov, S.: The European Pollen Database: past efforts and current activities, Veg. Hist. Archaeobot., 18, 417-424, 2009.

García-Herrera, R., Díaz, J., Trigo, R. M., Luterbacher, J. and Fischer, E. M.: A review of the European Summer heat wave of 2003, Crit. Rev. Environ. Sci. Technol., 40, 267-306, 2010.

Giesecke, T., Davis, B. A. S., Brewer, S., Finsinger, W., Wolters, S., Blaauw, M., de Beaulieu, J. L., Binney, H., Fyfe, R. M., Gaillard, M. J., Gil-Romera, G., van der Knaap, W. O., Kunes, P., Kuhl, N., van Leeuwen, J. F. N., Leydet, M., Lotter, A. F., Ortu, E., Semmler, M., and Bradshaw, R. H. W.: Mapping the late Quaternary vegetation of Europe: chronologies, uncertainties, 
and other improvements within the European Pollen Database, doi:10.1007/s00334-012-0390-y, 23, 75-86, 2013.

Gillett, N. P.: Climate modelling - Northern Hemisphere circulation, Nature, 437, 496-496, 2005.

Gladstone, R. M., Ross, I., Valdes, P. J., Abe-Ouchi, A., Braconnot, P., Brewer, S., Kageyama, M., Kitoh, A., Legrande, A., Marti, O., Ohgaito, R., Otto-Bliesner, B., Peltier, W. R., and Vettoretti, G.: Mid-Holocene NAO: A PMIP2 model intercomparison, Geophys. Res. Lett., 32, L16707, doi:10.1029/2005g1023596, 2005.

Guiot, J., Harrison, S. P., and Prentice, I. C.: Reconstruction of Holocene Precipitation Patterns in Europe Using Pollen and Lake-Level Data, Quat. Res., 40, 139-149, 1993.

Harff, J., Endler, R., Emelyanov, E., Kotov, S., Leipe, T., Moros, M., Olea, R., Tomczak, M., and Witkowski, A.: Late Quaternary Climate Variations Reflected in Baltic Sea Sediments, Baltic Sea Basin, 99-132, 2011.

Harrison, S. P., Bartlein, P. J., Brewer, S., Prentice, I. C., Boyd, M., Hessler, I., Holmgren, K., Izumi, K., and Willis, K.: Climate model benchmarking with glacial and mid-Holocene climates, Clim. Dynam., 43, 671-688, doi:10.1007/s00382-013-1922-6, 2013.

Hawkins, E. and Sutton, R.: The Potential to Narrow Uncertainty in Regional Climate Predictions, B Am. Meteorol. Soc., 90, 1095, doi:10.1175/2009bams2607.1, 2009.

Hoy, A., Jaagus, J., Sepp, M., and Matschullat, J.: Spatial response of two European atmospheric circulation classifications (data 1901-2010), Theoret. Appl. Climatol., 112, 73-88, 2013.

Huntley, B. and Birks, H. J. B.: An atlas of past and present pollen maps for Europe: 0-13000 years ago, Cambridge University Press, Cambridge, 1983.

Huntley, B. and Prentice, I. C.: July temperatures in Europe from pollen data, 6000 years before present, Science, 241, 687-690, 1988.

Hurrell, J. W.: Decadal Trends in the North-Atlantic Oscillation - Regional Temperatures and Precipitation, Science, 269, 676679, 1995.

Hurrell, J. W., Kushnir, Y., Ottersen, G., and Visbeck, M.: An overview of the North Atlantic Oscillation, Geophys. Monogr., 134, 1-35, 2003.

Ionita, M., Lohmann, G., Rimbu, N., and Scholz, P.: Dominant modes of Diurnal Temperature Range variability over Europe and their relationships with large-scale atmospheric circulation and sea surface temperature anomaly patterns, J. Geophys. Res.Atmos., 117, D15111, doi:10.1029/2011jd016669, 2012.

IPCC: Climate Change 2013: The Physical Science Basis, Contribution of Working Group I to the Fifth Assessment Report of the Intergovernmental Panel on Climate Change, edited by: Stocker, T. F., Qin, D., Plattner, G.,-K., Tignor, M., Allen, S. K., Boschung, J., Nauels, A., Xia, Y., Bex, V., Midgley, P. M., Cambridge University Press, Cambridge, United Kingdom and New York, NY, USA, 1535 pp., 2013

Jarvis, A., Reuter, H. I., Nelson, A., and Guevara, E.: Hole-filled SRTM for the globe Version 4, available from the CGIAR-CSI SRTM 90 m Database (http://srtm.csi.cgiar.org), 2008

Jones, P. D. and Lister, D. H.: The influence of the circulation on surface temperature and precipitation patterns over Europe, Clim. Past, 5, 259-267, doi:10.5194/cp-5-259-2009, 2009.

Jonsson, C. E., Andersson, S., Rosqvist, G. C., and Leng, M. J.: Reconstructing past atmospheric circulation changes using oxygen isotopes in lake sediments from Sweden, Clim. Past, 6, 49-62, doi:10.5194/cp-6-49-2010, 2010.

Joussaume, S. and Taylor, K. E.: Status of the Paleoclimate Modeling Intercomparison Project (PMIP), 425-430, 1995.

Juggins, S.: Quantitative reconstructions in palaeolimnology: new paradigm or sick science? Quaternary Sci. Rev., 64, 20-32, 2013.

Kalnay, E., Kanamitsu, M., Kistler, R., Collins, W., Deaven, D., Gandin, L., Iredell, M., Saha, S., White, G., Woollen, J., Zhu, Y., Chelliah, M., Ebisuzaki, W., Higgins, W., Janowiak, J., Mo, K. C., Ropelewski, C., Wang, J., Leetmaa, A., Reynolds, R., Jenne, R., and Joseph, D.: The NCEP/NCAR 40-year reanalysis project, B Am. Meteorol. Soc., 77, 437-471, 1996.

Kjellstrom, E., Nikulin, G., Hansson, U., Strandberg, G., and Ullerstig, A.: 21 st century changes in the European climate: uncertainties derived from an ensemble of regional climate model simulations, Tellus A, 63, 24-40, 2011.

Küttel, M., Luterbacher, J., and Wanner, H.: Multidecadal changes in winter circulation-climate relationship in Europe: frequency variations, within-type modifications, and long-term trends, Clim. Dynam., 36, 957-972, 2011.

Kysely, J. and Huth, R.: Changes in atmospheric circulation over Europe detected by objective and subjective methods, Theoret. Appl. Climatol., 85, 19-36, 2006.

Lu, J. M., Kim, S. J., Abe-Ouchi, A., Yu, Y. Q., and Ohgaito, R.: Arctic Oscillation during the Mid-Holocene and Last Glacial Maximum from PMIP2 Coupled Model Simulations, J. Climate, 23, 3792-3813, 2010.

Lunt, D. J., Abe-Ouchi, A., Bakker, P., Berger, A., Braconnot, P., Charbit, S., Fischer, N., Herold, N., Jungclaus, J. H., Khon, V. C., Krebs-Kanzow, U., Langebroek, P. M., Lohmann, G., Nisancioglu, K. H., Otto-Bliesner, B. L., Park, W., Pfeiffer, M., Phipps, S. J., Prange, M., Rachmayani, R., Renssen, H., Rosenbloom, N., Schneider, B., Stone, E. J., Takahashi, K., Wei, W., Yin, Q., and Zhang, Z. S.: A multi-model assessment of last interglacial temperatures, Clim. Past, 9, 699-717, 2013, http://www.clim-past.net/9/699/2013/.

Macias-Fauria, M., Forbes, B. C., Zetterberg, P., and Kumpula, T.: Eurasian Arctic greening reveals teleconnections and the potential for structurally novel ecosystems, Nat. Clim. Change, 2, 613618, 2012.

Masson, V., Cheddadi, R., Braconnot, P., Joussaume, S., Texier, D., and Pmip: Mid-Holocene climate in Europe: What can we infer from PMIP model data comparisons?, Clim. Dynam., 15, 163182, 1999.

Mauri, A., Davis, B. A. S., Collins, P. M., and Kaplan, J. O.: The climate of Europe during the Holocene: a gridded pollen-based reconstruction and its multi-proxy evaluation, Quat. Sci. Rev., submitted, 2014.

Nesje, A., Matthews, J. A., Dahl, S. O., Berrisford, M. S., and Andersson, C.: Holocene glacier fluctuations of Flatebreen and winter-precipitation changes in the Jostedalsbreen region, western Norway, based on glaciolacustrine sediment records, Holocene, 11, 267-280, 2001.

Milankovich, M.: Kanon der Erdbestrahlung und seine Anwendung auf das Eiszeitenproblem: Special Publications, v. 132, Section of Mathematics and Natural Sciences, v. 33, Belgrade, Königliche Serbische Akademie, 1941.

NOAA: Northern Hemisphere Teleconnections, http://www.cpc. ncep.noaa.gov/data/teledoc/telecontents.shtml, 2011. 
Otto-Bliesner, B. L., Rosenbloom, N., Stone, E. J., McKay, N. P., Lunt, D. J., Brady, E. C., Overpeck, J. T.: How warm was the last interglacial? New model-data comparisons, Phil. Trans. R. Soc. A, 371, 20130097, doi:10.1098/rsta.2013.0097, 2013.

Otto, J., Raddatz, T., Claussen, M., Brovkin, V., and Gayler, V.: Separation of atmosphere-ocean-vegetation feedbacks and synergies for mid-Holocene climate, Geophys. Res. Lett., 36, L09701, doi:10.1029/2009GL037482, 2009.

Rimbu, N., Lohmann, G., Lorenz, S. J., Kim, J. H., and Schneider, R. R.: Holocene climate variability as derived from alkenone sea surface temperature and coupled ocean-atmosphere model experiments, Clim. Dynam., 23, 215-227, 2004.

Sepp, M. and Jaagus, J.: Frequency of circulation patterns and air temperature variations in Europe, Boreal Environ. Res., 7, 273279, 2002.

Seppa, H. and Birks, H. J. B.: July mean temperature and annual precipitation trends during the Holocene in the Fennoscandian tree-line area: pollen-based climate reconstructions, Holocene, 11, 527-539, 2001.

Thompson, D. W. J. and Wallace, J. M.: The Arctic Oscillation signature in the wintertime geopotential height and temperature fields, Geophys. Res. Lett., 25, 1297-1300, 1998.

Trouet, V., Esper, J., Graham, N. E., Baker, A., Scourse, J. D., and Frank, D. C.: Persistent Positive North Atlantic Oscillation Mode Dominated the Medieval Climate Anomaly, Science, 324, 78-80, doi:10.1126/science.1166349, 2009.

Trouet, V., Panayotov, M. P., Ivanova, A., and Frank, D.: A panEuropean summer teleconnection mode recorded by a new temperature reconstruction from the northeastern Mediterranean (ad 1768-2008), Holocene, 22, 887-898, 2012.

van Oldenborgh, G. J., Drijfhout, S., van Ulden, A., Haarsma, R., Sterl, A., Severijns, C., Hazeleger, W., and Dijkstra, H.: Western Europe is warming much faster than expected, Clim. Past, 5, 112, doi:10.5194/cp-5-1-2009, 2009. van Ulden, A. P. and van Oldenborgh, G. J.: Large-scale atmospheric circulation biases and changes in global climate model simulations and their importance for climate change in Central Europe, Atmos. Chem. Phys., 6, 863-881, doi:10.5194/acp-6863-2006, 2006.

Vial, J. and Osborn, T. J.: Assessment of atmosphere-ocean general circulation model simulations of winter northern hemisphere atmospheric blocking, Clim. Dynam., 39, 95-112, 2012.

Visbeck, M. H., Hurrell, J. W., Polvani, L., and Cullen, H. M.: The North Atlantic Oscillation: Past, present, and future, P. Natl. Acad. Sci. USA, 98, 12876-12877, 2001.

Vork, K. A. and Thomsen, E.: Lusitanian/Mediterranean ostracods in the Holocene of Denmark: Implications for the interpretation of winter temperatures during the postglacial temperature maximum, Holocene, 6, 423-432, 1996.

Wanner, H., Beer, J., Bütikofer, J., Crowley, T. J., Cubasch, U., Flückiger, J., Goosse, H., Grosjean, M., Joos, F., Kaplan, J. O., Küttel, M., Müller, S. A., Prentice, I. C., Solomina, O., Stocker, T. F., Tarasov, P. E., Wagner, M., and Widmann, M.: Mid- to late Holocene climate change - an overview, Quaternary Sci. Rev., 27, 1791-1828, 2008.

Wohlfahrt, J., Harrison, S. P., and Braconnot, P.: Synergistic feedbacks between ocean and vegetation on mid- and high-latitude climates during the mid-Holocene, Clim. Dynam., 22, 223-238, 2004.

Woollings, T.: Dynamical influences on European climate: an uncertain future, Philos. T. R. Soc. A., 368, 3733-3756, 2010.

Wu, H. B., Guiot, J. L., Brewer, S., and Guo, Z. T.: Climatic changes in Eurasia and Africa at the last glacial maximum and midHolocene: reconstruction from pollen data using inverse vegetation modelling, Clim. Dynam., 29, 211-229, 2007.

Yiou, P., García de Cortázar-Atauri, I., Chuine, I., Daux, V., Garnier, E., Viovy, N., van Leeuwen, C., Parker, A. K., and Boursiquot, J.-M.: Continental atmospheric circulation over Europe during the Little Ice Age inferred from grape harvest dates, Clim. Past, 8, 577-588, doi:10.5194/cp-8-577-2012, 2012. 